\title{
Tax Payers Consultative Year 2015: There Is a Dramaturgy?
}

\author{
Puspa Ayu Lauty ${ }^{1}$, Theresia Woro Damayanti ${ }^{2}$ \\ 1,2Faculty of Economics and Business, Universitas Kristen Satya Wacana, \\ Indonesia
}

Email: woro@staff.uksw.edu

\begin{abstract}
This research examines about dramaturgy of the implementation of Tax Payer Consultative Year 2015 at Kantor Pelayanan Pajak Pratama Semarang Candisari. The purpose of this rearch is to describe and analyze the implementation of Tax Payer Consultative Year 2015 policy as a dramaturgy at Kantor Pelayanan Pajak Pratama Semarang Candisari. This research is a qualitative research using descriptive analysis and interviewing techniques directly to the informant. The number of respondents in this research were 8 people. The results of this research indicate that there was dramaturgy on the implementation of Tax Payer Consultative Year 2015 at Kantor Pelayanan Pajak Pratama Semarang Candisari. Proven by the compatibility between the criterias about the behavior of dramaturgy of Tax Payer Consultative Year 2015 policy and the criterias according to the theory of dramaturgy by Goffman (1959), which is used as a reference in this research.
\end{abstract}

Keywords: Dramaturgy, Tax Payer Consultative Year 2015

JEL : M48

DOI : 10.24002/kinerja.v22i2.1810

Received: 12-03-2018 Reviewed: 14-04-2018 Final Version: 12-09-2018

\section{INTRODUCTION}

In order to improve tax compliance in Indonesia, 2015 was designated as the Indonesian 2015 Tax Amnesty or called Tahun pembinaan Wajib Pajak 2015 (Tax Payer Consultative Year 2015). The Directorate General of Taxes of the Republic of Indonesia provided a policy on the annulment of tax administration penalties for the taxpayer who fails to pay or deposit taxes in addition to those who have not reported or corrected the tax calculation report and also the amount of tax to be 
paid or deposited. Because the tax is a transfer form of individual wealth to the country, then the property being transferred is not as big as if the tax penalties are remain subjected.

Iskandar (2015) explains that tax amnesty is the annulment of tax administration penalties for taxpayers who fails to pay or deposit taxes in addition to those who have not reported or corrected the tax calculation report and also the amount of tax to be paid or deposited. The important point is that the penalties subtracted to the demand of the taxpayer are penalties in the form of fine and interest from the reporting and payment delays.

In the Regulation of the Minister of Finance of the Republic of Indonesia No. 29/PMK.03/2015 article 1 paragraph (3) it is stated that administrative penalties are administrative sanctions in the form of an interest rate of $2 \%$ (two percent) per month that is raised because the tax debts are not paid or underpaid as stipulated in Article 19 paragraph (1) of the General Provisions of Taxation Act. While the annulment of administrative penalties in the Regulation of the Minister of Finance of the Republic of Indonesia Number 29/PMK.03/2015 article 1, paragraph (4) is the annulment of remaining administrative penalties in tax bill that have not been paid for by the taxpayer.

There are four types of tax amnesty (Silitonga, 2012). The first is the amnesty that obliges the tax principal payment, including the interest and fine, and only remits the tax criminal penalty. The purpose is to levy the tax of the previous years, as well as to increase the number of the registered taxpayer. The second that is a little loose, is the amnesty which requires the payment of the past tax principal and the interest, but remits the fine penalty and the tax criminal penalty. The third that is looser is the amnesty that still requires the payment of the past tax principal, but remits the interest penalty, fine penalty, and the tax criminal penalty. The fourth is the loosest form of amnesty since it remits the tax principal in the past, including the interest penalty, fine penalty, and tax criminal penalty. The purpose is to gain more registered taxpayers, so that they will begin to pay taxes in the future and further.

Taxpayer's disobedience is seen as an error on a lack of understanding of the importance of taxes and the lack of understanding of the tax provisions. So that, along with the end of the Tax Payer Consultative Year 2015 it is expected that public awareness to implement the tax obligations can be increased voluntarily. However, instead of to raise taxation awareness of the taxpayer, the policy allegedly aims to increase the State tax revenue. It can be seen as a dramaturgy behavior.

Dramaturgy, or better known as the theory of self is where the human social life in interaction anywhere, anytime will always show themselves as theater actors that the appearance may change any time depending on the context (Goffman, 1959). This study highlights the behavioral aspects of dramaturgy in the implementation of Tax Payer Consultative Year 2015 policy. Through the analysis 
of the dramaturgy behavior it can be seen the behavior of the individuals concerned in playing their scenes and role plays.

From the above explanation it can be seen that the tax authorities may explore the potential of tax revenue through the Tax Payer Consultative Year 2015. This study empirically proved that there was a dramaturgy in the Tax Payer Consultative Year 2015, namely a condition when the Tax Payer Consultative Year 2015 policy is implemented as the tax amnesty in 2015 and the law enforcement in 2016 is used by the tax authorities to play their camouflage roles that the policy is intended to raise awareness of the taxpayer, so they seem to fight for the public interests.

Therefore, this study aims to describe the dramaturgy of the implementation of Tax Payer Consultative Year 2015, so as to obtain a description of the behavior displayed by the individuals concerned in the implementation of the policy. The results of this study are expected to provide insight the application of dramaturgy in tax system.

\section{LITERATURE REVIEW}

\subsection{Dramaturgy}

Dramaturgy explains that human identity is unstable and every identity is a part of self psychological psychology (Goffman, 1959). Human identity may change depending on the interaction with other people. According to Goffman, dramaturgy concept views the social life as a drama performance show which is illustrated by the role of people who interact and connect with the social reality that they face through a stage by using a predetermined storyline. Goffman (1959: 22) explains some of the things that underlie the dramaturgy theory, namely:

a. Performance, it refers to all individual activities that occur during a specific period.

b. Front stage, the front area that refers to the events that indicate that the individual displays formal role. They are playing a role on the theatrical stage in front of the audiences.

c. Setting, a situation that must be physically present when the individuals perform. It includes furniture, decoration, layout, and background objects that support a series of individual actions on the stage. For example, a surgeon requires an operating room, a taxi driver requires the vehicle, and so forth.

d. Appearance, it refers to the tools that are considered by the audience as the equipment carried by an actor individual into the settings and are used to state the social status of the actor individuals. For example, a doctor wears white medical coat with a stethoscope hanging around his neck. 
e. Manner (style), is an action or role to be played by the actors. This includes facial expressions, posture, dress and so forth that serve to tell about the role of the interaction of the actors.

Widodo (2010: 167) explains that dramaturgical theory is a theory that explains that social interaction is interpreted the same as the theater show or drama on a stage. Man is an actor who seeks to combine the personal characteristics and purposes to others, through his personal drama. The key words in the dramaturgy are show, impression, front region, back stage, setting, appearance and style. The proportions are as follows:

a. All social interactions have front region which is similar with theatrical performances. Actors in both the stage and in everyday life, equally attract attention because of the appearance of the costumes worn and the equipment used.

b. In the daily show there is a back region which is a place that allows the actors to prepare for the next show.

c. In discussing the performance, an individual can present a performance (show) for others, but the impression of the actor may vary.

d. There is a front stage and a back stage. The front stage is the appearance of an individual, who regularly function in common mode, still defines the situation which see the appearance. These include setting and personal front which are further divided into appearance (impression) and style (manner).

\subsection{Dramaturgy of the Implementation of Tax Payer Consultative Year 2015}

Referring to the dramaturgical theory presented by Goffman (1959: 22), dramaturgy can be applied in the implementation of Tax Payer Consultative Year 2015 as follows:

a. Performance, it refers to the activities undertaken by the actors in implementing tax amnesty program in 2015, and the law enforcement carried out in 2016 . The activities include socialization and counseling, serving consultation from the taxpayers, and conducting supervision.

b. Dramaturgy refers to human behavior that has a dual role as an effort to gain self-image by performing impression management when interacting with others. The social life is divided into a front stage and a back stage. Front stage is used by the actors to display the theatrical roles, where the tax employees perform their activities. With the people who come and see the performance of the employees they try to show the best practices of them. Meanwhile, back stage is the situation when these employees back into themselves and blend with their surroundings prepare all of the activities they will perform related to this policy. 
c. Setting, it indicates the procedures and background objects that support the existing activities. For example, in front of the entrance gate outdoor media are placed such as banners and billboards related to tax amnesty and the law enforcement period. In the office also seen some standing banner to provide information at a glance in order to convince the audience (society).

d. Appearance, it describes the social class of an actor. It can be seen from the way they dress. They wore clean and tidy uniforms so that at a glance it can explain that they had a good capacity to do the job.

e. Manner (style), it refers to how the employees perform their activities, to make interactions between actors. The imaging is seen such as when the Account Representative extends things related to the tax amnesty and law enforcement period to the people who come to the office. They explain with a warm facial expression, say a good and courteous language to provide closer social interaction to the community than the actual social distance.

Based on the definition of the two concepts of dramaturgy and tax amnesty program at the time of the implementation of Tax Payer Consultative Year 2015 policy, we can develop a definition of the dramaturgy in the implementation of the Tax Payer Consultative Year 2015. Dramaturgy in the implementation of Tax Payer Consultative Year 2015 can be defined as a condition when the Tax Payer Consultative Year 2015 policy was implemented as the tax amnesty year in 2015 and it was used by the tax authorities to play their camouflage role that the policy was intended to raise awareness of the taxpayer, and they were seen fighting for the sake of public interest, so that the public might obtain complete construction as if the plots they made were true.

\section{RESEARCH METHODS}

The method used in this study was descriptive qualitative study methods. Qualitative study method as revealed by Sugiyono (2012a) is that the data are obtained directly from the source orally (by interviews) so that the data are collected in the form of words or images that do not emphasize the number (Sugiyono, 2012b). Meanwhile, according to Sarosa (2012: 7) Qualitative study is a study that attempts to understand phenomena in their natural setting and context (not in the laboratory) where researchers are not trying to manipulate the observed phenomena.

The location of this study was at Primary Tax Office Semarang Candisari, which is located at Jalan Setiabudi 3 Semarang. The sampling technique used here was purposive sampling, i.e. the sampling technique where the samples were chosen with consideration and specific purposes (Sugiyono, 2012). Data source in this study was primary data by using data collection technique of direct interviews to the speakers at the Primary Tax Office Semarang Candisari. 
Respondents in this study were sources or informants at the Primar Tax Office Semarang Candisari namely the members of Account Representative. The number of respondents was not determined by the considerations of respondents. In collecting the data, the study was based on the saturation of the data and information provided by the respondents. If some respondents stated the same information, then it is considered sufficient for the process of collecting the necessary data.

Steps of data analysis in this study are described in the stages as follows:

a. Analysis prior to field survey

Before conducting a survey in the field, the researchers conducted an analysis of various data related to the dramaturgy of tax amnesty and law enforcement period through papers, thesis, and writing in the form of books, articles, journals, and other writings found in various print and electronic media.

b. The analysis in the field by using Miler and Hubberman (1992)

1) Data Reduction

Data reduction was the first step in analyzing the data in this study. Once the data were obtained and collected from the field by direct interview to the informants, the next step was to summarize the data. In this study, the reduced aspects were the interviews concerning the dramaturgy of the implementation of Tax Payer Consultative Year 2015. Some things that underlie the theory of dramaturgy stated by Goffman (1959) are performance, front stage and back stage, setting, appearance and manner.

2) Presentation of the data

The first thing to do in the process of presenting the data in this study was a general depiction through the analysis of data from interviews about the activities undertaken by the tax authorities, especially the actors in implementing Tax Payer Consultative Year 2015 policy. After that, the next step was to describe the dramaturgy of the implementation of Tax Payer Consultative Year 2015 of several criteria: performance, front stage and back stage, setting, appearance, and the manner (style).

3) Conclusion construction

In this step, the researchers noted all the phenomena that arose in the dramaturgy of the implementation of Tax Payer Consultative Year 2015. Of the various activities in question, the researchers can make conclusions based on the data that has been discovered.

\section{ANALYSIS AND DISCUSSION}

Below will be described the discussion on the dramaturgy of the implementation of Tax Payer Consultative Year 2015 obtained from the interviews to the 
informants, namely Account Representative at Primary Tax Office Semarang Candisari. Each field identification result is shown by the explanation below.

\title{
4.1 Performance
}

The first thing that underlies the dramaturgy theory by Goffman (1959) is the performance, which is something that refers to all the individual activities that occur during a specific period. There was couple of activities performed during the policy period. The first, to obtain a relief in the form of tax sanctions removal, the taxpayer should perform $3 \mathrm{M}$ steps that were to calculate, report, deposit the tax obligations and followed the subsequent procedures that have been established, namely the submission along with the files that must be completed. After that, Account Representative would perform a tax reconciliation calculation on the tax obligations of the taxpayer which have not been fulfilled. Service to the public was also carried out by the tax authorities to get sympathy from the public. For example, by providing socialization, counseling, and consultation service, as expressed by a member of Account Representative I, Mr. Bramanto:

\begin{abstract}
"In Indonesia we know the tax collection system of "self-assessment system" where the taxpayers should do 3M: to calculate, deposit and report tax obligations by themselves. In the self-assessment system there must be intentional or unintentional mistakes in conducting 3M. Those mistakes could cause underpayment of tax liabilities and tax penalties even cause an administrative fine. In 2015, the Directorate General of Taxation issued a policy of tax sanctions removal, with a reconciliation of tax penalty on the tax obligation that has not been fulfilled. So the taxpayer will only pay the tax principal. Taxpayers usually come to the office and they ask questions first. The tax sanctions removal has some procedures, so the taxpayer must follow and complement the established procedure first. After that, they calculate the tax penalty imposed on them. If the amount is material they want to join this program by paying the tax principal amount to be paid and then we could eliminate the administrative sanctions"
\end{abstract}

\subsection{Director}

The next dramaturgy criteria is the director. Referring to Goffman's theory, Harymawan (1988: 63) explains that the director is an employee who coordinates all the elements of the theater with the understanding, skills, and intelligent imagination so as to achieve a successful performance. For this criterion, the researchers asked two questions about the actual reason and purpose of the policy implementation.

"This policy was carried out to give a chance to the taxpayers in order to be willing to report their tax obligations properly. The policy is conducted in terms of language of hectic arguably "discount". Because the tax penalties is generally too high of $2 \%$ per month from the time limit specified. So maybe in 
normal conditions it becomes very difficult to pay. Thus in 2015 ago, taxpayers were given the opportunity and were encouraged to report their tax correctly. And 2016 is the year of law enforcement, so they are related. If last year the taxpayers had been given the opportunity and they do not want to take advantage, we comply with the rules of Law that is penalties in accordance with applicable regulations. The first thing that underlies the authorities is that we see that the tax revenue has not been too encouraging. Secondly, there are still many Taxpayers who have not reported their tax obligations properly. On the one hand, we have limited data that we may not be able to access entirely. Thus, we tend to encourage the taxpayers to follow the program voluntarily or in assessment way. "(Supriyono Gunawan, Head of Waskon II Section)."

The actors who appear to implement this policy were the Account Representative at Primary tax office Semarang Candisari and the society was positioned as a theatrical lovers. From the interview it can be seen that, the reason for the enactment of this policy was because of the central office command which was motivated by several things. Among other were the low degree of compliance and understanding of the tax, the insufficient completeness of the database, and state tax revenue that has not been encouraging. So, the puppeteer or the director of this policy is the central office of the Directorate General of Taxation who authorized and assigned the members to implement this policy.

\subsection{Backstage}

Referring to Goffman's theory on dramaturgy, Widodo (2010) explains that the key dramaturgical theory after the performance is backstage (behind the stage), is a back region which is a place that allows the actors to prepare for the next show. Mr. Toha as a member of Account Representative Waskon I stated that:

"Usually it is about the socialization and counseling. That's important since it can let people know if we have a new program. If they do not know, the policy is not able to run. Before we perform a counseling, we usually do some kind of little discussion in the office with other members on duty to do counseling. We discuss about who the counseling targets are, where the place is, who the material presenter is. Yeea... some things like that."

The actors prepared themselves to start the activities in Primary tax Office Semarang Candisari, in the back stage they began to develop a plan and strategy to run its activities. For example is meetings and discussions prior to the socialization and counseling to the public related to this policy.

\subsection{Setting and Front stage}

According to Goffman (1959) Setting, a situation that must be physically present when the individuals perform. It includes furniture, decoration, layout, and background objects that support a series of individual actions on the stage. While 
front stage the front area that refers to the events that indicate that the individual displays formal role. They are playing a role on the theatrical stage in front of the audiences. To further reassure the public about this policy, officers continue to strive to do the massive socialization, by performing the placement of the the background objects to support the activities of the actors. For example, the placement of outdoor media (billboard and banners) in public places such as roads, crossroads, traffic lights, and shopping centers. In addition, the actors also made advertisements in electronic media such as radio, television, and internet. Socialization in the form of face to face communication was also done in government offices and enterprises.

So that it can be seen, front stage was used by the actors to show their role in several places. The main thing was at Primary Tax Office Semarang Candisari itself where the major activities were carried out here. And in other supporting areas, among others in the government offices and business entities in which they socialized this policy face-to-face. Further, down the highway, shopping centers, and other public places that allow people to see and read about the promotion of the new program in progress.

\subsection{Appearance}

In his book, Goffman (1959) describes the appearance as to the tools that are considered by the audience as the equipment carried by an actor individual into the settings and are used to state the social status of the actor individuals.

To obtain a good impression from the public, the impression management committed by the actors is essential. It includes their appearance. For example, the regulation regarding the use of uniform. In the counseling or socialization activities the actors wore special uniforms in accordance with their orders. The use of uniforms had also been set up on daily work schedules. Eith a neat uniforms it was expected that at a glance it can explain that they had a good capacity to do the job.

\subsection{Manner (style)}

Manner (style), is an action or role to be played by the actors. This includes facial expressions, posture, dress and so forth that serve to tell about the role of the interaction of the actors. Here are the excerpts of interview with Mrs. Hilda Kamalia, a member of Account Representative Waskon II, who gave a statement that:

"Resistance remains. The taxpayers refuse, bid, and persevere. Even if the taxpayers have data, it is sometimes difficult for them to pay taxes, because there is no tax returns directly to the people behind it. It is different with retribution. Yes we still try to continue to give them explanation well, if they 
consult we will serve them well. But if they still refuse, it is their own risk. This year is the year of law enforcement so there will be more firm sanctions."

From the interview results, 5 of 8 respondents answered that the most important thing to do is to build relationships and good communication to the public. For example, when a taxpayer want to consult, then the Account Representative will serve them well. There is also a taxpayer who chooses to communicate via telephone. It is no doubt if many taxpayers who sometimes behave less favorably to the tax officials. They must still respond them well, with the polite words so that the relationship between the tax officials and the taxpayers is good. With well established communication, it is expected that the taxpayer will feel more comfortable and confident to tax officers.

The imaging from the actors was very real as demonstrated by the statements of some respondents that, to attract the attention of the public, tax authorities gave the lure or bonus as a reward to the community. They thought that this policy was their sales material. They sell policy, and then they got tax revenues. So the exemption of tax sanctions was only as a "sweetener" so that people were more interested in following this policy.

The impression conveyed by the tax officers to the community for the efforts they are doing is considered successful and received positive responses from the public. Of the eight respondents who were interviewed said that people enthusiasm for this policy was very big. It was evidenced by so many people who came to the Primary Tax Office Semarang Candisari to follow the applicable procedure so that there was overload payment.

\section{CONCLUSION}

Based on the analysis of the study and discussion that have been presented, it can be concluded that there was a dramaturgy in the implementation of Tax Payer Consultative Year 2015 at Primary Tax Office Semarang Candisari. It is evidenced by the existence of correspondence between the criteria concerning the behavior of dramaturgy in the implementation of the Tax Payer Consultative Year 2015 policy with the criteria according to the dramaturgy theory by Goffman (1959) which is used as reference in this study.

There are a couple of things as the background of the policy. Mainly because of the authority and orders from the central office that requires all tax regional offices in Indonesia to implement this policy. Other things underlying this policy are the lack of state tax revenue, the lack of public awareness of the tax and inadequate completeness of the data base.

Mastery of the drama was shown in impression management to the public through the front next of their drama. Such as through the appearance and manner of dress, methods of information delivery and communication to the public through consultation, socialization and counseling, as well as supporting the use of objects 
such as outdoor media (billboards and banners) and electronic media (internet, television and radio). Imaging is more visible when they made a statement related to the annulment of tax penalties as a sweetener in implementing this policy. Bonuses include removing tax penalties will be given to taxpayers who want to pay off the tax obligations in 2015.

The results of this study imply that, Tax Payer Consultative Year 2015 actually intended to increase the overall tax revenue and to complete data base of taxpayers. By granting an exemption on tax administrative penalties, the tax authorities expect the public to be more interested in following this policy which will be followed by an increase in the overall tax revenue. It can be revealed from the results of interviews that have been submitted that this policy was successful to get the public sympathy as evidenced by the occurrence of the overload payments from the public.

\section{REFERENCES}

Alm, James. 1998. Tax Policy Analysis: The Introduction of Russian Tax Amnesty. Working Paper, Georgia State University.

Basrowi dan Suwandi. 2008. Memahami Penelitian Kualitatif. Jakarta: PT. Rineka Cipta.

Danim, Sudarwan. 2002. Menjadi Peneliti Kualitatif. Bandung: CV. Pustaka Setia.

Fitri, Ainal. 2015. "Dramaturgi: Pencitraan Prabowo Subianto Di Media Sosial Twitter Menjelang Pemilihan Presiden 2014". Jurnal Interaksi, Vol. 4, No. 1, Januari.

Goffman, Erving. 1959. The Presentation Of Everyday Life. New York: Doubleday. Harymawan. 1988. Dramaturgi. Bandung: CV Rosda.

Iskandar, Hendar. 2015. "Ampunan Yang Berjenjang." Direktorat Jenderal Pajak Kementrian Keuangan, September 25. http://www.pajak.go.id/content/article/ampunan-yang-berjenjang (diakses pada hari Kamis tanggal 29 Oktober 2015).

Miles, Matthew B., dan Huberman A. Michael. 1992. Analisis Data Kualitatif: Buku Sumber Tentang Metode-Metode Baru. Penerbit Universitas Indonesia.

Parle, W.M., and Hirlinger, Mike. W. 1986. Evaluating The Use Of Tax Amnesty By State Government. New York Times

Ragimun. 2014. "Analisis Implementasi Pengampunan Pajak (Tax Amnesty) di Indonesia". Kementrian Keuangan Republik Indonesia, November 04. http://kemenkeu.go.id/Kajian/analisis-implementasi-pengampunan-pajaktax-amnesty-di-indonesia (diakses pada hari Rabu 19 Oktober 2016). 
Ratung, T. dan Adi, P.H. 2009. "Dampak Kebijakan Sunset Policy Terhadap Faktor-Faktor Yang Mempenggaruhi Kemauan Membayar Pajak". SImposium Nasional Perpajakan II, Fakultas Ekonomi Universitas Trunojoyo Madura

Rechberger et al. 2010. Tax Amnesty, Justice Perceptions, and Filling Behaviour: A Simulation Study. Law \& Policy, Vol. 32, No. 2.

Sabarguna, Boy S. 2005. Analisis Data Pada Penelitian Kualitatif. Jakarta: Penerbit Universitas Indonesia.

Sarosa, Samiaji. 2012. Penelitian Kualitatif: Dasar-Dasar. Jakarta Barat: Indeks.

Silitonga, Erwin. 2012. "Ekonomi Bawah Tanah, Pengampunan Pajak, dan Referendum." Direktorat Jenderal Pajak Kementrian Keuangan, Juni 30. http://www.pajak.go.id/content/ekonomi-bawah-tanah-pengampunan-pajakdan-referendum (diakses pada hari Kamis tanggal 29 Oktober 2015).

Sudjana. 1990. Teknik Analisis Data Kualitatif. Bandung: Tarsito.

Sugiyono. 2012. Memahami Penelitian Kualitatif. Bandung: CV Alfabeta.

Sugiyono. 2012. Metode Penelitian Kombinasi. Bandung: CV Alfabeta.

Suneki, Sri., dan Haryono. 2012. "Paradigma Teori Dramaturgi Terhadap Kehidupan Sosial". Civis, Vol. II, No. 2, Juli. 1-4.

Widodo, Suko. 2010. Anatomi dan Perkembangan Teori Sosial. Malang: Aditya Media Publishing. 